\title{
The Effect of Training, Compensation and Work Discipline on Job Satisfaction that Impacts Employee Performance PT. Astra Honda Motor
}

\author{
Zulfikar Akbar ${ }^{1} \square$ and Nanang Agung Rohmandiyas ${ }^{2}$ \\ ${ }_{12}$ Program Studi Magister Manajemen, Binus Business School, Binus University, Indonesia \\ $\square$ Corresponding Author: Zulfikar Akbar, E-mail: zulfikar.akbar@binus.ac.id
}

ARTICLE INFORMATION ABSTRACT

Received: 01 October 2021

Accepted: 22 October 2021

Published: 24 November 2021

DOI: $10.32996 / j b m s .2021 .3 .2 .23$

\section{KEYWORDS}

Training, Compensation, Work Discipline, Job Satisfaction, and Employee Performance
This study aims to determine the effect of training, compensation, and work discipline on job satisfaction that has an impact on the performance of employees of PT. Astra Honda Motor. This research uses a case study method with a quantitative research methodology that uses 200 respondents from PT. Astra Honda Motor in the Engineering Plant Division 1 to Plant 5, Purchasing Division ( $P \& P C$ ) Plant 2, Procurement Plant 2 Division, PPIC Plant 1 Division to Plant 5. In this study, the Likert scale was used to model the questionnaire. The statistical testing technique in this study is multiple linear regression and hypothesis testing using the SPSS series 22 program. Meanwhile for mahalanobise distance test, path analysis, and trimming use the Amos series 22 program.

\section{Introduction}

PT. Astra Honda Motor (AHM) is a pioneer in the motorcycle industry in Indonesia, which was established on June 11, 1971, with the initial name PT. Federal Motors. Currently PT. Astra Honda Motor has 20,000 employees. To face increasingly competitive business competition, companies need to manage human resources well. So we need employees who have competence and integrity in their work. Several factors are required to improve employee performance, including training, compensation, and work discipline factors associated with job satisfaction factors. The purpose of this study was to determine the significance of the effect of training, compensation, and work discipline on employee performance mediated by job satisfaction on employees of PT. Astra Honda Motor.

\subsection{Relationship Between Variables and Research Hypotheses}

\subsubsection{Effect of Training on Job Satisfaction.}

The effect of training on job satisfaction is found in the results of the training programs provided by the company to employees. Because with effective and efficient training programs that are held on an ongoing basis, it will be able to improve employee competencies. So that employees can perform activities well, and this can lead to job satisfaction. Then this is reinforced by several previous research results, including:

1. Research conducted by Vasudevan (2014) entitled "Examining the Relationship of Training on Job Satisfaction and Organizational Effectiveness." The results of the research on training commitment, assessment of training needs, training materials, approaches, and evaluation of training affect employees' work commitment, job satisfaction, and performance.

2. Research conducted by Raza et al. (2017) entitled "Impact of Training on Employees Performance and Job Satisfaction: An Empirical Study of Plastic Industry of Hayatabad Industrial Estate". The results of this study found that training had a positive and significant impact on employee performance and job satisfaction.

Furthermore, the research hypothesis on the effect of training on job satisfaction, namely:

H1: There is a positive and significant effect between training (X1) on job satisfaction (Z) for employees of PT. Astra Honda Motor.

Copyright: (c) 2021 the Author(s). This article is an open access article distributed under the terms and conditions of the Creative Commons Attribution (CC-BY) 4.0 license (https://creativecommons.org/licenses/by/4.0/). Published by Al-Kindi Centre for Research and Development, London, United Kingdom. 


\subsubsection{Effect of Compensation on Job Satisfaction.}

The effect of compensation on job satisfaction will provide enthusiasm and work motivation significantly. Because compensation is the main factor in terms of employee satisfaction, so that employees will feel valued by the company for the contribution of energy, thought, and expertise provided by employees to the company. This is further strengthened by several research results, including:

1. Research conducted by Gopinath (2016) entitled "How The Compensation Management and Welfare Measure Influence Job Satisfaction? A Study with Special Reference in Bsnl to Three Different Ssas Using Modeling". With research results, BSNL has a good compensation management system, which is equivalent to industry standards.

2. Research conducted by Munguogo et al. (2015) entitled "Effects of Compensation on Job Satisfaction Among Secondary School Teachers in Maara Sub - County of Tharaka Nithi County, Kenya". The results of this study found that compensation is one of the incentives that motivate workers.

Then the research hypothesis on the effect of compensation on job satisfaction, namely:

\section{H2: There is a positive and significant effect between compensation (X2) on job satisfaction (Z) on employees of PT. Astra} Honda Motor.

\subsubsection{Effect of Work Discipline on Job Satisfaction.}

The effect of work discipline (X3) on job satisfaction (Z) positively impacts the company. Because employees who have a high level of discipline will always do work with pleasure so that it will directly affect job satisfaction. Then this is reinforced by several previous research results, including:

1. Afianto \& Utami's (2017) research entitled "The Effect of Work Discipline and Organizational Communication on Job Satisfaction and Employee Performance." With the results of the study, there is a significant effect of work discipline (X1) on job satisfaction (Y1). The diversity of data in this model is 0.910 , which means that information about the data is equal to $(91.0 \%)$.

2. Research conducted by Hardiyanti (2018) has the title "The Role of Job Satisfaction Intervening on the Effect of Work Discipline and Career Development on Employee Performance at the Faculty of Economics and Business, Sultan Ageng Tirtayasa University." With the results of research on the relationship between work discipline and job satisfaction, it has $t$-statistics (0.959) and p-values (0.344). This shows that the work discipline variable has no effect on job satisfaction because the t-statistic value $(0.959)<(1.96)$ and $p$-values $(0.344)>0.05$.

Furthermore, research hypotheses about the effect of work discipline on job satisfaction, namely:

H3: There is a positive and significant influence between work discipline (X3) on job satisfaction (Z) on employees of PT. Astra Honda Motor.

\subsubsection{Effect of Training on Employee Performance.}

The effect of training on employee performance has a positive impact on the company. Because employees who have been trained will be able to carry out job duties properly, furthermore, this is reinforced by several previous research results, including:

1. Research conducted by Omran (2016) with the title "Examining the Effect of Training Strategies on Employee Performance in the Libyan Construction Industry." With the results of the research on the level of perception of the training strategy and this study concluded that there was no significant relationship between gender, age, education level, and promotion with training objectives, but there was a significant relationship between all dimensions of training and development. human resources for training purposes. In addition, it can be said that demographic variables have no significant effect on the training objectives.

2. Research conducted by Khanfar, et al. (2014) with the title "Training and its Important in the Efficiency of Employee's Performance in Five - Star Hotels in Jordan." With the results of research training programs in accordance with the needs of employees. Then there is no significant relationship between the objectives of the training program and increasing the level of employee efficiency in five-star hotels in Jordan.

Then the research hypothesis on the effect of training on employee performance, namely:

H4: Has a positive and significant influence between training (X1) on employee performance $(Y)$ on employees of PT. Astra Honda Motor. 


\subsubsection{Effect of Compensation on Employee Performance.}

The effect of compensation on employee performance will provide significant work motivation. Because compensation, according to researchers is a company strategy to be able to significantly improve individual performance and be able to retain employees, so that it will reduce the intensity level of employee turnover. Then this is reinforced by several previous research results, including:

1. Research conducted by Hameed, et al. (2014) entitled "Impact of Compensation on Employee Performance (Empirical Evidence from Banking Sector of Pakistan)." With the results of research, compensation has a positive impact on employee performance. Regression analysis shows that all independent variables have an insignificant and positive effect on employee performance.

2. Research conducted by Osibanjo, et al. (2015) entitled "Compensation packages: a strategic tool for employees' performance and retention". With the results of research, managers must ensure that rewards or remuneration are distributed to employees dynamically and continuously evaluated to ensure transparency and fairness for all employees. Thus avoiding employee turnover ensures the retention of passionate employees.

Furthermore, the research hypothesis on the effect of compensation on employee performance, namely:

H5: There is a positive and significant effect between compensation (X2) on employee performance $(Y)$ on employees of PT. Astra Honda Motor.

\subsubsection{Effect of Work Discipline on Employee Performance.}

The effect of work discipline on employee performance will result in good productivity. Because in general, employees who have a high level of work discipline will work using quality and quantity following the company's SOPs. Furthermore, this is reinforced by several previous research results on the effect of work discipline on employee performance, as follows:

1. Research conducted by Roeleejanto, et al (2015) entitled "Effects of Leadership, Competency, and Work Discipline on the Application of Total Quality Management and Employees' Performance for the Accreditation Status Achievement of Government Hospitals in Jakarta, Indonesia". With the results of the study, the significant effect of competence and work discipline on TQM and employee performance shows the importance of all members of the organization to maintain good communication, inspire and motivate each other to develop good relationships and collaborations.

2. The results of research conducted by Hersona \& Sidharta (2017) entitled "Influence of Leadership Function, Motivation, and Work Discipline on Employee Performance". With the results of research, work discipline has the weakest effect on employee performance in the Department of Manpower and Transmigration Karawang Regency, West Java.

Then the research hypothesis on the effect of work discipline on employee performance, namely:

H6: There is a positive and significant influence between work discipline (X3) on employee performance (Y) at PT. Astra Honda Motor.

\subsubsection{Effect of Job Satisfaction on Employee Performance}

The effect of job satisfaction on employee performance will result in good individual performance. Because if employees feel satisfied while working, it will undoubtedly cause feelings of pleasure in carrying out their work activities. Then this is reinforced by several previous research results, including:

1. Hittiarachi (2014) research entitled "Impact of Job Satisfaction on Job Performance of IT Professionals: With Special Reference to Sri Lanka." With the research results, the job satisfaction dimensions (salary, promotion, supervision, and work) on software engineers positively affect (16.7\%) so that engineers are satisfied with their work.

2. Research conducted by Inuwa (2016) entitled "Job Satisfaction and Employee Performance: An Empirical Approach". With the results of research job, satisfaction has a positive and significant influence on employee performance. This clearly indicates an increase in the level of job satisfaction of non-academic BASUG staff will also lead to improvement and higher performance.

Then the research hypothesis on the effect of job satisfaction on employee performance, namely:

H7: There is a positive and significant effect between job satisfaction (Z) on employee performance $(Y)$ on employees of PT. Astra Honda Motor. 
The conceptual model in this study aims to design research systematically. The conceptual model is a diagram of causality between certain factors that are believed to have an impact on an object of research. The framework of thinking aims to provide a systematic description of the object of research.

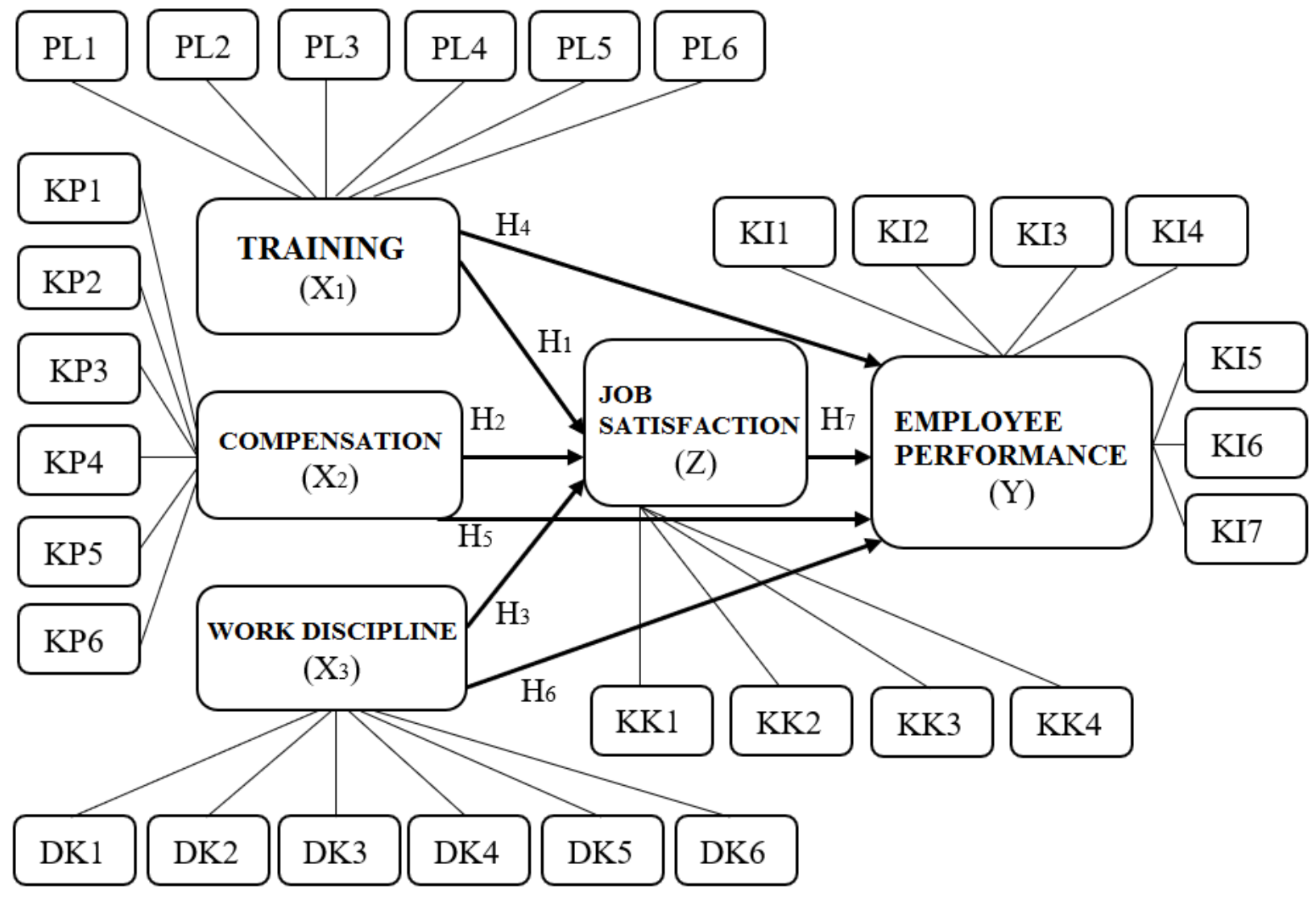

Figure 1.1 Thinking Framework

\section{Research Method.}

The sample analysis in this study used the Slovin technique with employees of PT. Astra Honda Motor has 400 respondents spread across the following Divisions: a) Engineering Division Plant 1 to Plant 5, b)Purchasing Division (P\&PC) Plant 2, c) Procurement Division Plant 2, d) PPIC Division Plant 1 to Plant 5.

Formula:

$$
\mathrm{n}=\mathrm{N} /\left(1+\mathrm{N}(\mathrm{e})^{2}\right)
$$

Criteria:

$$
\begin{array}{ll}
\mathrm{n} & =\text { Sample size } \\
\mathrm{N} & =\text { Population size } \\
\mathrm{e} & =\text { Error percentage }
\end{array}
$$

Population:

$(N)=20,000$ respondents assuming an error rate of $e=5 \%$, the number of samples $(n)$ is:

$$
\begin{aligned}
& n=20.000 /\left(1+20.000 .(0,05)^{2}\right) \\
& n=392.15=400
\end{aligned}
$$

The data collection technique in this study aims to obtain the data needed by researchers to analyze the phenomena or problems in this study. The primary data in this study came from a questionnaire using a Likert scale technique.

Table 2.1 Likert Scale

\begin{tabular}{lllll}
\hline Likert Scale & $\begin{array}{l}\text { Strongly } \\
\text { Disagree }\end{array}$ & Disagree & Neutral Agree & $\begin{array}{l}\text { Strongly } \\
\text { agree }\end{array}$ \\
\hline
\end{tabular}




$1 \quad 2 \quad 3 \quad 4 \quad 5$

There are three types of variables in this study, namely the independent variable (exogenous), the mediating variable (intervening), and the dependent variable (endogenous).

1. Exogenous Variable aims as a variable that affects the endogenous variable (the dependent variable), which is the factor that is measured by the researcher to determine the relationship between the observed phenomena. a) $\mathrm{X} 1=\mathrm{Training}$, b) $\mathrm{X} 2$ = Compensation, c) X3 = Work discipline.

2. Intervening Variable aims as a variable that affects the correlation between exogenous variables (independent variable) and endogenous variables (dependent variable). $Z$ = Job satisfaction.

3. Endogenous Variable aims as the dependent variable, namely the observation factor, and is measured to determine the relationship of exogenous variables, namely the factors that arise. $Y=$ Employee Performance.

Operational variables in this study are used to describe research variables, dimensions, and indicators.

\subsection{Pre-test Analysis}

\subsubsection{Validity Test}

The test of the research data instrument in this study is to compare the value of r-count with r-table for the degree of freedom $(\mathrm{df})=\mathrm{n}-2$, the sample in this study amounted to 50 respondents, then a correlation analysis was carried out between the statement score and the total score with the criteria if the statistical probability value $>5 \%$ significance level $=0.05$ then the item is declared valid.

\subsubsection{Reliability Test}

Reliability is a measuring tool that shows the stability of the data results and the possibility that the same researcher uses the measuring instrument at different times and vice versa, or at other times by using the basis for decision making using the Cronbach alpha technique because the research instrument has the form of a questionnaire with a Likert scale.

With an explanation, if alpha $>0.90$, it indicates perfect reliability. If the alpha value is between $0.60-0.90$, it means high reliability. If the alpha value is $0.50-0.70$, it means moderate reliability. If the alpha value $<0.50$ means low reliability. If the alpha value is low, it is possible that one or more items are not reliable.

\subsection{Main Test Analysis}

Respondents used in this research amounted to 400 people. In this study, the data testing technique used the following methods:

a. Multiple linear regression with classical assumption tests including normality, multicollinearity, heteroscedasticity, and linearity.

b. The test of mahalanoise distance.

c. Path analysis (path analyst).

d. Trimming test.

e. Hypothesis test ( $t$-test and $R^{2}$ )

\section{Results and Discussion.}

\subsection{Validity Test}

A validity test is a measure that shows the level of validity or validity of an instrument using 50 respondents. The results of this study are as follows:

Table 3.1 Validity Test Results

\begin{tabular}{lllllll}
\hline Variable & Statement & KMO & $\begin{array}{l}\text { Anti-Image } \\
\text { Correlation }\end{array}$ & $\begin{array}{l}\text { Component } \\
\text { Matrix }\end{array}$ & Validity \\
\hline Training & The training that I & 0,639 & 0,667 & 0,620 & Valid \\
\hline
\end{tabular}




\begin{tabular}{|c|c|c|c|c|c|}
\hline & accept according to work. & & & & \\
\hline & $\begin{array}{l}\text { The training I received was easy } \\
\text { to understand. }\end{array}$ & & 0,708 & 0,537 & Valid \\
\hline & $\begin{array}{l}\text { The training will improve my } \\
\text { work competence. }\end{array}$ & & 0,621 & 0,799 & Valid \\
\hline & $\begin{array}{l}\text { Training provides alternative } \\
\text { solutions to solve problems. }\end{array}$ & & 0,626 & 0,761 & Valid \\
\hline & $\begin{array}{l}\text { The training method I received } \\
\text { has been effective. }\end{array}$ & & 0,580 & 0,015 & Valid \\
\hline & $\begin{array}{l}\text { The training I have received has } \\
\text { been efficient. }\end{array}$ & & 0,628 & 0,182 & Valid \\
\hline Compensation & $\begin{array}{l}\text { The compensation that I receive } \\
\text { can increase work motivation. }\end{array}$ & 0,711 & 0,651 & ,612 & Valid \\
\hline & $\begin{array}{l}\text { The compensation that I } \\
\text { received it can increase my } \\
\text { creativity at work }\end{array}$ & & 0,802 & ,761 & Valid \\
\hline & $\begin{array}{l}\text { The compensation that I } \\
\text { received can improve work } \\
\text { competence }\end{array}$ & & 0,793 &, 500 & Valid \\
\hline & $\begin{array}{l}\text { The compensation that I receive } \\
\text { can increase work productivity. }\end{array}$ & & 0,674 & ,856 & Valid \\
\hline & $\begin{array}{l}\text { The compensation that I receive } \\
\text { can improve the quality of my } \\
\text { work. }\end{array}$ & & 0,697 & ,612 & Valid \\
\hline Work Discipline & $\begin{array}{l}\text { The workload that I receive is } \\
\text { appropriate }\end{array}$ & 0,775 & 0,882 & 0,777 & Valid \\
\hline & In my work, I feel idealistic & & 0,763 & 0,852 & Valid \\
\hline & $\begin{array}{l}\text { The workload I receive is in } \\
\text { accordance with the } \\
\text { compensation I get }\end{array}$ & & 0,727 & 0,832 & Valid \\
\hline & $\begin{array}{l}\text { Work discipline increases if } \\
\text { employee rights are fulfilled }\end{array}$ & & 0,742 & 0,755 & Valid \\
\hline Job satisfaction & $\begin{array}{l}\text { The management company's } \\
\text { decision is fair }\end{array}$ & 0,703 & 0,749 & 0,834 & Valid \\
\hline & $\begin{array}{l}\text { Company regulations can } \\
\text { discipline employees well. }\end{array}$ & & 0,819 & 0,831 & Valid \\
\hline & $\begin{array}{l}\text { Job rotation can increase } \\
\text { competence. }\end{array}$ & & 0,707 & 0,616 & Valid \\
\hline & $\begin{array}{l}\text { The job desk given is } \\
\text { appropriate }\end{array}$ & & 0,760 & 0,878 & Valid \\
\hline Variable & Statement & KMO & $\begin{array}{l}\text { Anti-Image } \\
\text { Correlation }\end{array}$ & $\begin{array}{l}\text { Component } \\
\text { Matrix }\end{array}$ & Validity \\
\hline Job satisfaction & $\begin{array}{l}\text { Office transportation facilities } \\
\text { make me comfortable }\end{array}$ & 0,703 & 0,679 & 0,893 & Valid \\
\hline & $\begin{array}{l}\text { Employee food facilities make } \\
\text { me comfortable }\end{array}$ & & 0,680 & 0,851 & Valid \\
\hline & $\begin{array}{l}\text { Schoolchildren scholarship } \\
\text { compensation makes me happy }\end{array}$ & & 0,692 & 0,535 & Valid \\
\hline $\begin{array}{l}\text { Employee } \\
\text { performance }\end{array}$ & $\begin{array}{l}\text { Ability and skills are in } \\
\text { accordance with the job desk }\end{array}$ & 9,723 & 0,669 & 0,765 & Valid \\
\hline & I have a good work ethic & & 0,678 & 0,854 & Valid \\
\hline & $\begin{array}{l}\text { Adequate work environment } \\
\text { comfort and safety }\end{array}$ & & 0,829 & 0,798 & Valid \\
\hline & The technology I use is adequate & & 0,828 & 0,721 & Valid \\
\hline
\end{tabular}




\begin{tabular}{llll}
\hline $\begin{array}{l}\text { My advantages have been } \\
\text { identified and optimized by } \\
\text { management }\end{array}$ & 0,650 & 0,076 & Valid \\
\hline $\begin{array}{l}\text { Management supports me to } \\
\text { keep learning and improving my } \\
\text { knowledge }\end{array}$ & 0,723 & 0,267 & Valid \\
\hline
\end{tabular}

Source: Primary data processed, 2017

Based on the results of table 3.1 for the variables of training, compensation, work discipline, job satisfaction, and employee performance, which is seen from the significance probability value $>0.05$, all variables in this study can be analyzed further. KMO value $>0.5$, which means KMO requirements are met. Each anti-image correlation value on each indicator is $>0.5$ and fulfills the MSA requirements. The component matrix values have significant results for each hand. Through the results of the data, the researcher concludes that all indicators in this study are valid.

\subsection{Reliability Test}

A construct or variable is said to be reliable if it gives a Cronbach alpha value $>0.60$ as follows:

Table 3.2: Reliability Test Results

\begin{tabular}{lll}
\hline Variable & Cronbach's Alpha & Conclusion \\
\hline Training & 0,619 & Reliable \\
\hline Compensation & 0,734 & Reliable \\
\hline Work Discipline & 0,890 & Reliable \\
\hline Job satisfaction & 0,826 & Reliable \\
\hline Employee performance & 0,792 & Reliable \\
\hline
\end{tabular}

Source: Primary data processed, 2017

Based on the results of the data table 3.2, the researcher concludes that all variables in this study have a significance level of $>5 \%$ or 0.05 , which means that all of these variables are declared reliable and feasible to be tested for the primary test.

\subsection{Classical Assumption Test.}

The most appropriate regression parameter is obtained using the OLS (Ordinary Least Square) method of least squares to get the equation. The OLS method can be used as an unbiased estimate if it meets the BLUE (Best Linear Unbiased Estimation) requirements.

\subsubsection{Normality Test}

Table: 3.3 Normality Test Results

\begin{tabular}{lllllll}
\hline Variable & Min & Max & Skew & C.r. & Kurtosis & C.r. \\
\hline Work Discipline & 12.63 & 26.44 & -0.009 & -0.075 & -0.851 & -3.467 \\
\hline Compensation & 5 & 19.18 & -0.136 & -1.107 & -0.277 & -1.13 \\
\hline Training & 6 & 20.4 & 0.324 & 2.638 & -0.481 & -1.958 \\
\hline Satisfaction & 5 & 17.91 & 0.089 & 0.727 & -0.814 & -3.314 \\
\hline Employee performance & 6 & 22.25 & -0.119 & -0.972 & 0.329 & 1.338 \\
\hline Multivariate & & & & & -0.902 & -1.075 \\
\hline
\end{tabular}

Source: Primary data processed, 2017

Based on the data in table 3.3, it is known that the c.r. (critical) skewness or c.r (essential) kurtosis is between -2.58 and 2.58. So it can be concluded that all data in this study are normally distributed, including the results of the multivariate numbers, because all data are below 2.58 and above -2.58 .

\subsubsection{Multicollinearity Test}

Table 3.4: Multicollinearity Test Results

Model

$\begin{array}{cl}\text { Collinearity } & \text { Tolerance } \\ \text { Statistics } & \text { VIF }\end{array}$




\begin{tabular}{lcc}
\hline Training * Satisfaction &, 983 & 1.017 \\
\hline Compensation * Satisfaction &, 983 & 1.017 \\
\hline Work Discipline * Satisfaction & 1,000 & 1.000 \\
\hline Training * Employee Performance &, 944 & 1.060 \\
\hline Compensation*Employee Performance &, 919 & 1.088 \\
\hline Work Discipline * Employee Performance &, 978 & 1.023 \\
\hline Satisfaction * Employee Performance &, 869 & 1.151 \\
\hline
\end{tabular}

Source: Primary data processed, 2017

Based on the results of the data table 3.4, it is known that each exogenous variable has collinearity statistics $>0.1$ and VIF tolerance $<10$. Then it can be concluded that all of the above variables do not occur multicollinearity.

\subsubsection{Heteroscedasticity Test}

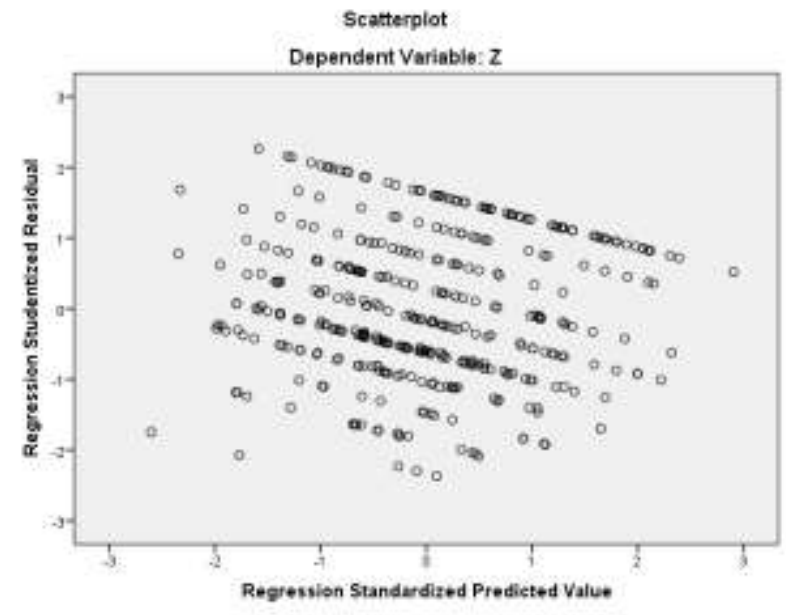

Figure 3.1: Structure 1 of Heteroscedasticity Test Results Source: Primary data processed, 2017

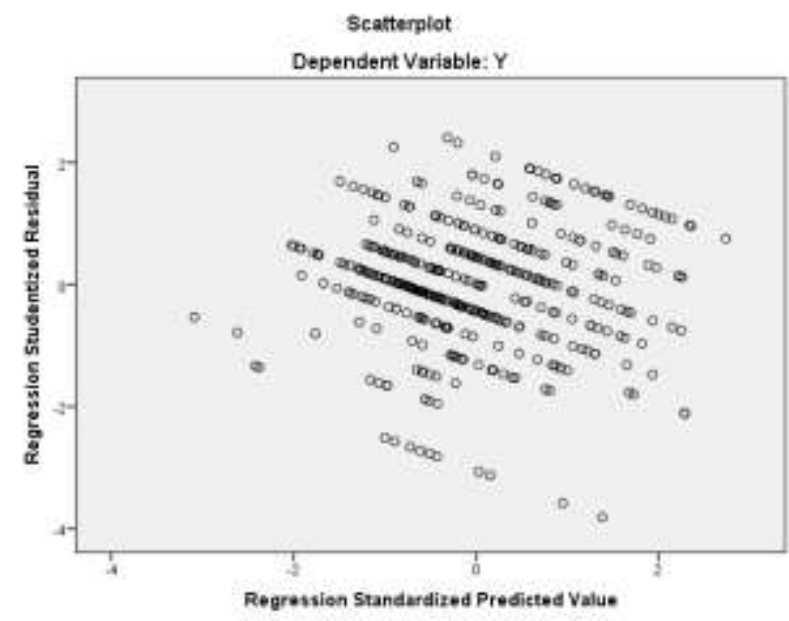

Figure 3.2: Structure 2 of Heteroscedasticity Test Results Source: Primary data processed, 2017

Based on the data results in Figures 3.1 and 3.2, it can be concluded that the points spread with an unclear pattern and are below the number 0 on the $\mathrm{Y}$-axis. Therefore, the researcher concludes that there is no heteroscedasticity problem in the substructure 1 and substructure 2 regression models.

\subsubsection{Linearity Test}

Table 3.5: Linearity Test Results 


\begin{tabular}{llcc}
\hline ANOVA Table & & & \\
\hline Variable & Sum of Squares & Mean Square & Sig. \\
\hline Training * Satisfaction & 199.627 & 199.627 &, 000 \\
\hline Compensation * Satisfaction & 295.894 & 295.894 &, 000 \\
\hline Work Discipline * Satisfaction & 78.963 & 78.963 &, 004 \\
\hline Training * Employee Performance & 315.911 & 315.911 &, 000 \\
\hline Compensation*Employee Performance & 596.329 & 596.329 &, 000 \\
\hline Work Discipline * Employee Performance & 79.848 & 79.848 &, 009 \\
\hline Satisfaction * Employee Performance & 561.570 & 561.570 &, 000 \\
\hline
\end{tabular}

Source: Primary data processed, 2017

Based on the data, table 3.5 shows that all variables have a significant value of deviation from linearity $<0.05$. It can be concluded that all variables have a linear relationship so that the linearity assumption is met.

\subsection{Mahalanobise Distance Test}

Table 3.6: Mahalanobise Distance Test Results

\begin{tabular}{|c|c|c|c|c|c|c|c|}
\hline $\begin{array}{l}\text { Observation } \\
\text { number }\end{array}$ & $\begin{array}{l}\text { Mahalanobise } \\
\text { d-squared }\end{array}$ & p1 & p2 & $\begin{array}{l}\text { Observation } \\
\text { number }\end{array}$ & $\begin{array}{l}\text { Mahalanobise } \\
\text { d-squared }\end{array}$ & p1 & p2 \\
\hline 290 & 21,512 & 0,001 & 0,228 & 283 & 8,386 & 0,136 & 0,963 \\
\hline 50 & 20,282 & 0,001 & 0,073 & 159 & 8,333 & 0,139 & 0,962 \\
\hline 170 & 19,495 & 0,002 & 0,025 & 16 & 8,306 & 0,14 & 0,956 \\
\hline 89 & 18,263 & 0,003 & 0,022 & 287 & 8,258 & 0,143 & 0,954 \\
\hline 361 & 15,026 & 0,01 & 0,391 & 163 & 8,251 & 0,143 & 0,94 \\
\hline 329 & 14,79 & 0,011 & 0,3 & 274 & 8,205 & 0,145 & 0,937 \\
\hline 367 & 13,348 & 0,02 & 0,705 & 143 & 8,195 & 0,146 & 0,921 \\
\hline 209 & 13,09 & 0,023 & 0,681 & 88 & 8,182 & 0,146 & 0,903 \\
\hline 24 & 11,515 & 0,042 & 0,988 & 354 & 8,175 & 0,147 & 0,879 \\
\hline 264 & 11,515 & 0,042 & 0,974 & 298 & 8,131 & 0,149 & 0,875 \\
\hline 49 & 11,513 & 0,042 & 0,951 & 333 & 8,117 & 0,15 & 0,852 \\
\hline 369 & 11,434 & 0,043 & 0,932 & 147 & 8,083 & 0,152 & 0,842 \\
\hline 232 & 11,384 & 0,044 & 0,902 & 393 & 8,077 & 0,152 & 0,809 \\
\hline 365 & 11,274 & 0,046 & 0,886 & 131 & 8,072 & 0,152 & 0,773 \\
\hline 193 & 11,197 & 0,048 & 0,859 & 400 & 7,974 & 0,158 & 0,815 \\
\hline 112 & 10,801 & 0,055 & 0,934 & 279 & 7,75 & 0,171 & 0,925 \\
\hline 208 & 10,649 & 0,059 & 0,938 & 389 & 7,608 & 0,179 & 0,96 \\
\hline 352 & 10,639 & 0,059 & 0,907 & 339 & 7,596 & 0,18 & 0,951 \\
\hline 177 & 10,63 & 0,059 & 0,866 & 395 & 7,596 & 0,18 & 0,935 \\
\hline 169 & 10,361 & 0,066 & 0,918 & 239 & 7,573 & 0,181 & 0,926 \\
\hline 134 & 10,206 & 0,07 & 0,93 & 122 & 7,518 & 0,185 & 0,932 \\
\hline 368 & 10,162 & 0,071 & 0,912 & 150 & 7,478 & 0,187 & 0,932 \\
\hline 328 & 10,149 & 0,071 & 0,879 & 44 & 7,475 & 0,188 & 0,914 \\
\hline 48 & 10,103 & 0,072 & 0,854 & 164 & 7,461 & 0,189 & 0,899 \\
\hline 289 & 10,033 & 0,074 & 0,841 & 200 & 7,389 & 0,193 & 0,917 \\
\hline 168 & 9,931 & 0,077 & 0,844 & 396 & 7,353 & 0,196 & 0,915 \\
\hline 370 & 9,824 & 0,08 & 0,851 & 323 & 7,353 & 0,196 & 0,893 \\
\hline 5 & 9,474 & 0,092 & 0,948 & 14 & 7,308 & 0,199 & 0,896 \\
\hline 189 & 9,438 & 0,093 & 0,936 & 356 & 7,273 & 0,201 & 0,894 \\
\hline 186 & 9,397 & 0,094 & 0,923 & 336 & 7,264 & 0,202 & 0,875 \\
\hline
\end{tabular}




\begin{tabular}{|c|c|c|c|c|c|c|c|}
\hline 73 & 9,202 & 0,101 & 0,956 & 245 & 7,248 & 0,203 & 0,859 \\
\hline 238 & 9,122 & 0,104 & 0,957 & 320 & 7,242 & 0,203 & 0,834 \\
\hline 385 & 9,114 & 0,105 & 0,941 & 59 & 7,241 & 0,203 & 0,801 \\
\hline 359 & 9,029 & 0,108 & 0,944 & 144 & 7,204 & 0,206 & 0,801 \\
\hline 251 & 8,998 & 0,109 & 0,933 & 178 & 7,148 & 0,21 & 0,82 \\
\hline 313 & 8,86 & 0,115 & 0,953 & 375 & 7,114 & 0,212 & 0,817 \\
\hline 355 & 8,742 & 0,12 & 0,965 & 277 & 7,08 & 0,215 & 0,815 \\
\hline 133 & 8,659 & 0,123 & 0,968 & 199 & 7,033 & 0,218 & 0,827 \\
\hline 121 & 8,413 & 0,135 & 0,991 & 203 & 7,014 & 0,22 & 0,812 \\
\hline 288 & 8,411 & 0,135 & 0,986 & 30 & 6,991 & 0,221 & 0,801 \\
\hline 118 & 8,386 & 0,136 & 0,982 & 270 & 6,991 & 0,221 & 0,765 \\
\hline 358 & 8,386 & 0,136 & 0,974 & 254 & 6,957 & 0,224 & 0,764 \\
\hline $\begin{array}{l}\text { Observation } \\
\text { number }\end{array}$ & $\begin{array}{c}\text { Mahalanobise } \\
\text { d-squared }\end{array}$ & p1 & P2 & & & & \\
\hline 247 & 6,933 & 0,226 & 0,753 & & & & \\
\hline 158 & 6,894 & 0,229 & 0,759 & & & & \\
\hline 135 & 6,858 & 0,231 & 0,762 & & & & \\
\hline 255 & 6,858 & 0,231 & 0,723 & & & & \\
\hline 115 & 6,844 & 0,233 & 0,701 & & & & \\
\hline 235 & 6,844 & 0,233 & 0,658 & & & & \\
\hline 366 & 6,841 & 0,233 & 0,617 & & & & \\
\hline 130 & 6,719 & 0,242 & 0,736 & & & & \\
\hline 142 & 6,712 & 0,243 & 0,704 & & & & \\
\hline 262 & 6,712 & 0,243 & 0,663 & & & & \\
\hline 119 & 6,675 & 0,246 & 0,671 & & & & \\
\hline 386 & 6,668 & 0,247 & 0,637 & & & & \\
\hline 1 & 6,649 & 0,248 & 0,621 & & & & \\
\hline 378 & 6,645 & 0,248 & 0,581 & & & & \\
\hline 230 & 6,638 & 0,249 & 0,547 & & & & \\
\hline 26 & 6,616 & 0,251 & 0,533 & & & & \\
\hline
\end{tabular}

Source: Primary data processed, 2017

Based on the results of the data table 3.6, no outlier data was found, because the values of $p 1$ and $p 2>0.05$. Therefore, the mahalanoise distance test in this study was fulfilled.

\subsection{Path Analyst}

The direct and indirect effects on path analysis in this study are as follows:

Table 3.7: Direct and Indirect Effects Based on Path Diagram

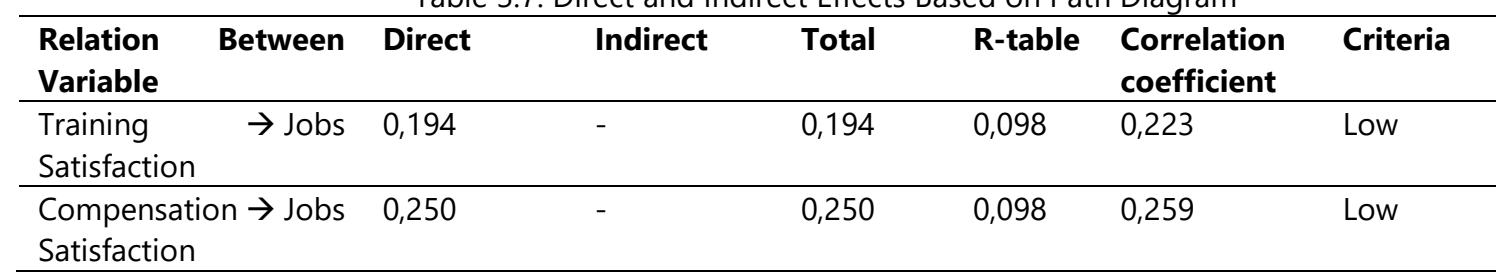




\begin{tabular}{|c|c|c|c|c|c|c|c|}
\hline $\begin{array}{l}\text { Work Discipline } \\
\text { Jobs Satisfaction }\end{array}$ & $\rightarrow$ & 0,141 & - & 0,141 & 0,098 & 0,140 & Very low \\
\hline $\begin{array}{l}\text { Training } \rightarrow \text { Employe } \\
\text { performance }\end{array}$ & & 0,178 & 0,043 & 0,221 & 0,098 & 0,207 & Low \\
\hline $\begin{array}{l}\text { Compensation } \\
\text { Employee } \\
\text { performance }\end{array}$ & $\rightarrow$ & 0,278 & 0,055 & 0,333 & 0,098 & 0,334 & Low \\
\hline $\begin{array}{l}\text { Work Discipline } \\
\text { Employee } \\
\text { performance }\end{array}$ & $\rightarrow$ & 0,100 & 0,031 & 0,131 & 0,098 & 0,165 & Very Low \\
\hline $\begin{array}{l}\text { Jobs Satisfaction } \\
\text { Employee } \\
\text { performance }\end{array}$ & $\rightarrow$ & 0,221 & - & 0,221 & 0,098 & 0,301 & Low \\
\hline
\end{tabular}

Source: Primary data processed, 2017

Based on the data from table 3.7, the researcher states the category of the influence of the relationship between the other variables (p) being studied where if the path coefficient is $0.05-0.09$, then the influence power is included in the weak category, if the path coefficient is $0.10-0.29$ then the power is categorized as weak. the influence is in the medium category; if the path coefficient is $>$ 0.30 then the impact is in the medium category. Therefore, the researcher describes as follows:

1. The variable directly influences job satisfaction with an effect of 0.194 or (19.4\%) and a correlation coefficient of 0.223 . This value shows the magnitude of the influence is low and accurate.

2. The compensation variable directly relates to job satisfaction with an influence magnitude of 0.250 or (25.0\%) and a correlation coefficient value of 0.259 . This value shows the extent of the influence is low and real.

3. The work discipline variable directly correlates with job satisfaction with a magnitude of 0.141 or (14.1\%) and a correlation coefficient of 0.223 . This value shows the magnitude of the influence is very low and real.

4. The variable has a decent direct relationship of 0.178 and a decent indirect relationship of 0.043 on employee performance with a total effect of 0.221 or (22.1\%) and a correlation coefficient value of 0.207 . This value shows the magnitude of the influence is low and real.

5. The compensation variable has a direct relationship worth 0.278 and an indirect relationship worth 0.055 on employee performance with a total effect of 0.333 or (33.3\%) and a correlation coefficient value of 0.334 . This value shows the magnitude of the influence is low and real.

6. The work discipline variable has a decent direct relationship of 0.100 and a decent indirect relationship of 0.031 on employee performance with a total effect of 0.131 or $(13.1 \%)$ and a correlation coefficient value of 0.165 . This value shows the magnitude of the influence is low and real.

7. The job satisfaction variable has a direct relationship worth 0.221 to employee performance with a total effect of $0.221(22.1 \%)$ and the correlation coefficient value is 0.301 . This value shows the magnitude of the influence is low and real.

Then seen from the results of the data table 3.7, it can be described using the IBM AMOS series 22 program as follows:

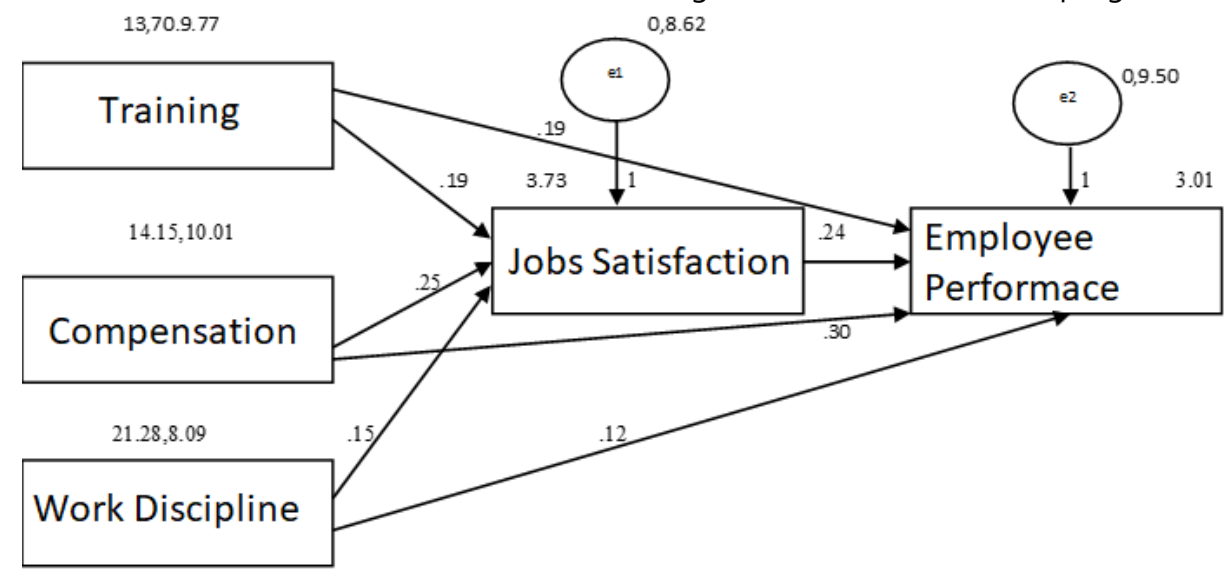


Figure 3.3: Test Results of Direct and Indirect Effects

Source: Primary data processed, 2017

\subsection{Hypothesis Test (t-Test and $R^{2}$ )}

Table 3.8: Structure 2 of $\mathrm{t}$-Test Results

\begin{tabular}{lllll}
\hline \multicolumn{2}{l}{ Regression Weights: (Group number 1 - Default model) } & & & \\
\hline Variable & Estimate & S.E. & C.R. & P \\
\hline Training $\rightarrow$ Employee performance & 0.192 & 0.051 & 3.768 & $* * *$ \\
\hline Compensation $\rightarrow$ Employee performance & 0.297 & 0.051 & 5.829 & $* * *$ \\
\hline Work Discipline $\rightarrow$ Employee performance & 0.115 & 0.053 & 2.168 & 0.030 \\
\hline Jobs Satisfaction $\rightarrow$ Employee performance & 0.237 & 0.053 & 4.502 & $* * *$ \\
\hline Source: Primary data processed, 2017 & &
\end{tabular}

Based on the significance test results for the job satisfaction variable, the t-count value was 4.502 , with a significance level of 0.00 $<0.05$. Then the researcher concluded that $\mathrm{H} 7$ was accepted and $\mathrm{HO}$ was rejected.

Table 3.9: Structure 1 of Determination Coefficient Test Results

\begin{tabular}{cc}
\hline \multicolumn{2}{c}{ Squared Multiple Correlations } \\
\hline Jobs Satisfaction & 0.120 \\
\hline \multicolumn{2}{c}{ Source: Primary data processed, 2017}
\end{tabular}

Based on the data in table 3.9, it can be seen from the acquisition of the R-Square value of 0.120 or (12\%). This is means that exogenous variables (training, compensation, and work discipline) simultaneously affect job satisfaction by 0.120 or (12\%). In comparison, the rest (88\%) is influenced by variables not discussed in this study, such as organizational commitment, development, motivation, and employee retention.

Table 3.10: Structure 2 of Determination Coefficient Test Results

\begin{tabular}{lc}
\hline \multicolumn{2}{l}{ Squared Multiple Correlations } \\
\hline $\begin{array}{l}\text { Employee } \\
\text { performance }\end{array}$ & 0.209 \\
\hline \multicolumn{2}{c}{ Source: Primary data processed, 2017 }
\end{tabular}

Based on the data in table 3.10, it can be seen from the acquisition of the R-Square value of 0.209 or (20.9\%). This means that exogenous variables (training, compensation, work discipline, and job satisfaction) simultaneously affect employee performance by 0.209 or $(20.9 \%)$. While the rest $(79.1 \%)$ is influenced by other variables not discussed in this study, such as organizational commitment, development, motivation, and organizational culture.

\section{Conclusions}

This study uses a case study that functions as a problem-solving test by analyzing the effect of training, compensation, work discipline on employee performance mediated by job satisfaction of employees of PT. Astra Honda Motor. The data collection technique in this study used a questionnaire with a Likert scale calculation and used descriptive interview techniques, namely interview techniques by approaching. Respondents in this study were employees of PT. Astra Honda Motor totaled 400 respondents. Based on the results of the study, the following results were obtained:

1. The effect of training on job satisfaction. From the study results, it can be concluded that there is an influence between activity and job satisfaction.

2. The effect of compensation on job satisfaction. From the study results, it can be concluded that there is an influence between compensation and job satisfaction.

3. The effect of work discipline on job satisfaction. From the study results, it can be concluded that there is an influence between work discipline and job satisfaction. 
4. The effect of training on employee performance. From the study results, it can be concluded that there is an influence between training on employee performance.

5. The effect of compensation on employee performance. From the results of the study, it can be concluded that there is an influence between compensation on employee performance.

6. The effect of work discipline on employee performance. From the study results, it can be concluded that there is an influence between work discipline on employee performance.

7. The effect of work discipline on employee performance. From the results of the study, it can be concluded that there is an influence between work discipline on employee performance.

\section{References}

[1] Afianto, I. D., Utami. H. N. (2017). Pengaruh Disiplin Kerja dan Komunikasi Organisasi Terhadap Kepuasan Kerja dan Kinerja Karyawan (Studi pada Karyawan Divisi Marketing, PT Victory International Future administrasibisnis.studentjournal.ub.ac.id. 50 (6): 58-67.

[2] Gopinath, R. (2016). How The Compensation Management and Welfare Measure Influence Job Satisfaction? A Study with Special Reference in Bsnl to Three Different Ssas Using Modeling. International Journal of Scientific Research. 5 (8): 305-308.

[3] Hameed, A., Ramzan, M., Zubair, H. M. K., Ali, G., Arslan, M. (2014). Compensation on Employee Performance (Empirical Evidence from Banking Sector of Pakistan). International Journal of Business and Social Science. 5 (2): 302-309.

[4] Hardiyanti, S. E. (2018). Peran Intervening Kepuasan Kerja Pada Pengaruh Disiplin Kerja dan Pengembangan Karir Terhadap Kinerja Pegawai Pada Fakultas Ekonomi dan Bisnis Universitas Sultan Ageng Tirtayasa. Tirtayasa EKONOMIKA Universitas Sultan Ageng Tirtayasa. 13 (2): 138-156.

[5] Hersona, S., Sidharta, I. (2017). Influence of Leadership Function, Motivation and Work Discipline on Employee Performance. Journal of Applied Management (JAM). 15 (3): 528-537.

[6] Inuwa, M. (2016). Job Satisfaction and Employee Performance: An Empirical Approach. The Millennium University Journal. 1 (1): 90-103.

[7] Khanfar, S. M. (2014). Training and its Important in the Efficiency of Employees' Performance in Five - Star Hotels in Jordan. Journal of Business Studies Quarterly, 6 (2): 137-158.

[8] Munguongo, M. M., Muguna, A. T., Muriithi, D. K. (2015). Effects of Compensation on Job Satisfaction Among Secondary School Teachers in Maara Sub - County of Tharaka Nithi County, Kenya. Journal of Human Resource Management. 3 (6): 47-59.

[9] Omran, A. (2016). Examining The Effect of Training Strategies on Employees Performance in The Libyan Construction Industry. Journal of Engineering Management and Competitiveness (JEMC). 6 (2): 99-110.

[10] Osibanjo, O. A., Adeniji, A. A., Falola, H. O., Heirsmac, P. T. (2014). Compensation packages: a strategic tool for employees' performance and Retention. Leonardo Journal of Sciences. 65-84. Issue 25, July-December.

[11] Roeleejanto, C., Brasit, N., Payagan, O. R., Pahlevi, C. (2015). Effects of Leadership, Competency, and Work Discipline on the Application of Total Quality Management and Employees' Performance for the Accreditation Status Achievement of Government Hospitals in Jakarta, Indonesia. Scientific Research Journal (SCIRJ), 3 (6): 14-24.

[12] Raza, K., Afridi, F. K., Khan, S. I. (2017). Impact of Training on Employees Performance and Job Satisfaction: An Empirical Study of Plastic Industry of Hayatabad Industrial Estate. Journal of Business and Tourism. 3 (1): 173-189.

[13] Vasudevan, H. (2014). Examining the Relationship of Training on Job Satisfaction and Organizational Effectiveness. Int. J. Manag. Bus. Res. 4 (3):185-202.

[14] Wibowo. (2014). Manajemen Kinerja, Edisi Keempat. Jakarta: PT RajaGrafindo Persada.

[15] Widodo. (2015). Metodologi Penelitian. Jakarta: PT RajaGrafindo Persada.

[16] Wirawan. (2009). Evaluasi Kinerja Sumber Daya Manusia. Jakarta: Salemba Empat. 